NBER WORKING PAPER SERIES

\title{
FISCAL DISCIPLINE AND THE COST OF PUBLIC DEBT SERVICE: SOME ESTIMATES FOR OECD COUNTRIES
}

\author{
Silvia Ardagna \\ Francesco Caselli \\ Timothy Lane \\ Working Paper 10788 \\ http://www.nber.org/papers/w10788
}

\author{
NATIONAL BUREAU OF ECONOMIC RESEARCH \\ 1050 Massachusetts Avenue \\ Cambridge, MA 02138 \\ September 2004
}

\begin{abstract}
We are grateful to Ignazio Angeloni, Pierluigi Balduzzi, Paolo Paesani, Fabio Schiantarelli, Ludger Schuknecht, Rolf Strauch, an anonymous referee, and to participants to the seminar at the European Central Bank Fiscal Policy Division for useful discussions and suggestions. The views expressed herein are those of the author(s) and not necessarily those of the National Bureau of Economic Research.

(C2004 by Silvia Ardagna, Francesco Caselli, and Timothy Lane. All rights reserved. Short sections of text, not to exceed two paragraphs, may be quoted without explicit permission provided that full credit, including (C) notice, is given to the source.
\end{abstract}


Fiscal Discipline and the Cost of Public Debt Service: Some Estimates for OECD Countries Silvia Ardagna, Francesco Caselli, and Timothy Lane

NBER Working Paper No. 10788

September 2004

JEL No. H6

\begin{abstract}
$\underline{\text { ABSTRACT }}$
We use a panel of 16 OECD countries over several decades to investigate the effects of government debts and deficits on long-term interest rates. In simple static specifications, a one-percentage-point increase in the primary deficit relative to GDP increases contemporaneous long-term interest rates by about 10 basis points. In a vector autoregression (VAR), the same shock leads to a cumulative increase of almost 150 basis points after 10 years. The effect of debt on interest rates is non-linear: only for countries with above-average levels of debt does an increase in debt affect the interest rate. World fiscal policy is also important: an increase in total OECD-government borrowing increases each country's interest rates. However, domestic fiscal policy continues to affect domestic interest rates even after controlling for worldwide debts and deficits.
\end{abstract}

\author{
Silvia Ardagna \\ Harvard University \\ sardagna@fas.harvard.edu \\ Francesco Caselli \\ Harvard University \\ Department of Economics \\ Littauer Building \\ Cambridge, MA 02138 \\ and NBER \\ caselli@harvard.edu \\ Timothy Lane \\ IMF \\ tlane@imf.org
}




\section{Introduction}

After years of fiscal consolidation in the 1990s, governments of many OECD countries have again embarked on expansionary fiscal policies. In 2003, the US government deficit reached 4.5 percent of GDP, compared with 1.5 percent in 2000, and is projected to increase further in the future. Over the same period, Germany's deficit rose to 3.75 percent of GDP from 1 percent; France's to 3.5 compared with 1.5, and Italy's to 2.5 from 0.75 percent; as a result, the Stability and Growth Pact has come under strain, possibly weakening the resistance to larger deficits in Europe in the future.

One of the main concerns raised by governments' increased fiscal laxity is its effect on long-term interest rates. Undergraduate macroeconomic textbooks teach that budget deficits push interest rates up, leading to decreased investment and growth in the long-run. However, many economists and policymakers have argued that more sophisticated theorizing leads to less dire predictions, if not to an outright reversal of the textbook story, or that the quantitative significance of the effect is likely to be small. ${ }^{1}$ Given that theory does not settle the matter (as it rarely does) the focus now is on empirical evidence.

The effects of fiscal imbalances on interest rates have been the subject of an extensive but hiterto inconclusive empirical literature. ${ }^{2}$ However, estimates of the impact of debts and deficits on interest rates vary widely. ${ }^{3}$ Almost all of this work is based on time series evidence from single countries, typically the US. This suggests that there may be significant benefits

\footnotetext{
${ }^{1}$ See Barth et al. (1991) and Gale and Orszag (2002) for a comprehensive review of the literature.

${ }^{2}$ An incomplete list includes Barro (1987), Barro and Sala-i-Martin (1990), Blanchard and Summers (1984), Canzoneri, Cumby and Diba (2002), Evans (1985) and (1987), Hoelscher (1986), Laubach (2003), Miller and Russek (1991) and (1996), Orr et al. (1995), Paesani and Strauch (2003), Perotti (2002), Plosser (1987), Reinhart and Sack (2000), and Tavares and Valkanov (2003).

${ }^{3}$ Coefficients of fiscal policy variables in interest rates regressions span from being positive and significant to being insignificant. For example, while Hoelscher (1986) finds that in the US each 100 billion dollars of federal deficit increases the 10-year Treasury bonds interest rate by about 143 basis points, Evans (1987) finds that eurocurrency rates are not sensitive to changes in the fiscal stance in Canada, France, Germany, Japan, the UK and the US. More recently, Canzoneri, Cumby and Diba (2002) show that in the US an increase in projected future deficit by one percentage point of GDP leads to an increase in long-term interest rates relative to the short-term interest rate from 53 to 60 basis points. This result is also supported by Laubach (2003) who finds that a one percentage point surge in the projected deficit-to-GDP ratio raises long-term interest rates in the US by about 25 basis points. To the contrary, in a VAR framework, Mountford and Uhlig (2000) do not find a permanent effect of deficit shocks on short-term interest rates, and Perotti (2002) shows that increases in government spending lead to a small decrease in the real short-term interest rates in the US.
} 
from bringing cross-country evidence to bear on this question. This is the goal of the present paper.

We examine the effects of fiscal policy on interest rates in a broad panel of 16 OECD countries covering a maximum time span from 1960 to 2002. The results indicate statistically and economically significant effects of fiscal imbalances on long-term interest rates. In our preferred specification, a one percentage point increase of the primary deficit-to-GDP ratio is associated with a 10-basis-point rise in the nominal interest rate on 10-year government bonds. The increase is larger when one also considers the effect that a positive shock to the primary deficit has on expected future fiscal policy and macro variables in the long-run: in a dynamic VAR a one percentage point increase in the primary deficit-to-GDP ratio leads to a cumulative increase of almost 150 basis points after 10 years.

In addition to the current deficit, it is important to examine the implications of changes in the stock of public debt. We find that the effect is non-linear and that the response of long-term interest rates is positive and statistically significant only when the stock of public debt is above a given threshold. While in a country with a debt-to GDP ratio of 119 per cent (Italy in 2002) a one-standard-deviation increase in government debt leads to an increase in the nominal interest rate on 10-year government bonds of about 36 basis points, an increase by the same amount where the public debt-to-GDP ratio is 58 percent (the US in 2002) leads to a 5 basis points decrease in the interest rate. ${ }^{4}$

We also find that a worsening of public finances abroad has an effect on national interest rates, which is evidence that OECD countries' financial markets are to some extent internationally integrated. However, the degree of globalization is far from complete: controlling for the average value of the primary deficit and public debt to GDP ratios across OECD countries, a shock to each country's primary balance still affects national long-term interest rates. ${ }^{5}$ In a similar vein, we investigate whether the impact of fiscal variables on interest rates is more severe in financially less developed countries, and we find some evidence to this effect.

The rest of the paper is organized as follows. Section 2 describes the data and the econometric technique used in the estimation. Section 3 investigates the relation between

\footnotetext{
${ }^{4}$ Note, however, that the ratio of government debt to GDP has a standard deviation equal to 26 per cent, hence a one-standard-deviation increase in the public debt is quite a substantial change. The response of interest rates to a one percent change of the stock of public debt to GDP ratio would be really minimal, even in countries with extreme low or high values of public debt.

${ }^{5}$ Besides incomplete financial-market integration, differential government default risks may also explain this result.
} 
fiscal policy and long-term interest rates in static models, tackles causality, expands the empirical analysis of our benchmark specifications and checks the robustness of the results. Section 4 presents estimates from dynamic VAR models. The last section concludes.

\section{Data and Method}

In this section we describe the data we use in the empirical analysis, discuss the choice of the variables of interest, and investigate the time-series properties of the variables.

The paper uses yearly data on OECD countries covering a maximum time span from 1960 to 2002. The countries included in the sample are: Australia, Austria, Belgium, Canada, Denmark, France, Germany, Ireland, Italy, Japan, The Netherlands, New Zealand, Spain, Sweden, United Kingdom, and United States. All fiscal and macroeconomic data are from the OECD Economic Outlook n.73, June 2003. Data on interest rates on 3-month Treasury bills and on 10-year government bonds are from Global Financial Data; data on 10-year interest rates on swap contracts are from Bloomberg. Data on financial development are from the World Bank database on Financial Development and Structure. ${ }^{6}$

Since the objective is to isolate the effects of fiscal policy on interest rates, we use a long-term bond rate as the dependent variable. A long-term rate reflects market conditions, including inflationary expectations, in contrast to short-term rates which are heavily influenced by current monetary policy. We focus on the nominal interest rate on 10-year government bonds (INT10Y) because OECD countries in the sample have been issuing this type of long-term bond for many years and, hence, long time-series of this variable are available. $^{7}$

Our key indicators of the fiscal stance refer to the general government and are the primary deficit as a share of GDP (PRDEF) and the public debt as a share of GDP (GDEBT1 or $G D E B T 2$ ). We use the primary deficit, rather than the total deficit, because it strips out the direct effect of interest rates on expenditure, thus better capturing autonomous changes in fiscal policy. We use two measures of government debt, GDEBT1 or GDEBT2, which

\footnotetext{
${ }^{6}$ The database available on line at http://www.worldbank.org/research/projects/finstructure/database.htm.

${ }^{7}$ The results are robust if, instead, the long-term interest rate series from the OECD, which is an average of the interest rates of long-term bonds of different maturities, is used as the dependent variable. The results also stand up if the spread between the 10-year government bonds interest rate and the 3-month Treasury bills interest rate is taken as the dependent variable, and if both rates are entered in real terms.
} 
differ in the way in which the variable is deflated. GDEBT1 is equal to the stock of public debt measured at the end of period t-1 divided by the level of GDP in year t-1. GDEBT2 is constructed following the approach in Levine et al (2002). It is a year-average debt stock (i.e. the average of the stock of public debt in year t-1 and in year t divided by GDP in year t) which insulates the debt ratio from within-year inflation.

Relative to other contributions in the literature our specification is slightly unusual, in that it includes both the deficit and the debt. Our reason for doing so is that in theory the relationship between fiscal policy and interest rates may be mediated by either variable. Textbook IS-LM accounts tend to emphasize the deficit, while microfounded general equilibrium models tend to place more weight on the stock of debt. Furthermore, even if one were specifically interested in the effects of only one of these variables, it would still make sense to control for the other. For example, given the current stock of debt, including the deficit may help controlling for the expected future path of the debt itself. Finally, including both variables will allow us to study interactions among them. For example, some of our specifications are designed to assess whether the effect of deficits depends on the level of debt.

To achieve identification we mainly follow the well-worn path of adding relevant control variables. The chief concern, of course, is to hold monetary policy constant. To this end, in all our specifications we include the nominal interest rate on 3-month Treasury bills $(I N T 3 M)$ and the inflation rate $(I N F L) .{ }^{8}$ We also control for the GDP growth rate $($ GROWTH $)$ and for global indicators of world fiscal imbalances. We typically also have a full set of country and year dummies. Finally, we use instrumental variables to allow for the possible endogeneity of fiscal policy associated with the government reaction function.

\subsection{Time Series Properties and Estimation Technique}

The stationarity properties of nominal interest rates (on 10-year government bonds and 3-month Treasury bills), the inflation rate, and the primary balance and public debt as a share of GDP were examined using the unit root test for panel data proposed by Im,

\footnotetext{
${ }^{8}$ In principle, this may lead us to underestimate the effect of fiscal shocks on interest rates, if such shocks impact the inflation rate and short-term rates directly or through the monetary authority's reaction function (see Canzoneri et al. (2002)). When we regress the three-month interest rate on our fiscal variables, however, we find no effect. Also, we show below that in a VAR that includes both short and long-term rates the impact effect of fiscal shocks on long-term rates is similar in magnitude to the one implied by the simple static regression that controls for short-term rates.
} 
Pesaran and Shin (2002). ${ }^{9}$ Table 1, part I, shows the results. While the evidence is against stationarity when we use the sample from 1960 till 2002 (Sample A, from now on), it is in favor of stationarity if we consider data from 1975 onwards (Sample B). This holds for all variables except for the two variables that measure the stock of public debt as a share of GDP, GDEBT1 and GDEBT2. In fact, the test result does not allow us the reject the null hypothesis that $G D E B T 1$ is $I(1)$ in both samples, but it suggests that $G D E B T 2$ is a stationary variable in Sample $A$ and Sample $B$. This mixed evidence on the order of integration of the series may well be due to the presence of structural breaks in the data around the oil-shock and to the inability of the test used to distinguish it from the presence of a unit-root. For this reason, we prefer not to choose any of the two types of results and we will estimate our specifications for both samples, using, in each case, the appropriate econometric technique.

For Sample A, we also test whether the nominal interest rate on 10-year government bonds, the nominal interest rate on 3-month Treasury bills, the inflation rate, the primary deficit to GDP ratio, and the public debt to GDP ratio, as measured by GDEBT1, are cointegrated using the tests suggested by Pedroni (1999) on the panel. The evidence allows us to reject the null hypothesis that the variables are not cointegrated (see Table 1, part II).

Hence, based on the results shown in Table 1, we estimate our models in levels. We always include country fixed effects, and linear and quadratic trends or year fixed effects. When Sample $A$ is used, we estimate the relation among the long-term interest rate, the short-term interest rate, the inflation rate and the fiscal policy variables by dynamic GLS, because OLS standard errors are not valid when variables are cointegrated. More precisely, in models using Sample A, we allow for heterosckedasticity and first order autocorrelation in the error term and include among the regressors the contemporaneous differences of the right-hand side variables. Both the autocorrelation coefficient and the coefficients of the contemporaneous differences of the right-hand side variables are allowed to be countryspecific. ${ }^{10}$ When we use Sample $B$, models are estimated by OLS and standard errors are

\footnotetext{
${ }^{9}$ When the augmented Dickey-Fuller (ADF) test was applied to data for each country, the results permitted rejection of the presence of a unit root for many, but not all, countries in the sample. The Im, Pesaran, and Shin test is preferred given the low power of the ADF in small samples and the desirability of adopting the same dynamic specification for the entire panel.

${ }^{10}$ Stock and Watson (1993), and Mark and Sul (2002) suggest including contemporaneous, leads and lags values of the differences of the right-hand side variables among the regressors and to allow the coefficients of these variables to be country specific. Due to the number of observations required to estimate many country's specific coefficients, we follow Schiantarelli et al. (1999) in including only the contemporaneous
} 
corrected for heterosckedasticity. OLS estimation in levels with country fixed effects (in addition to linear and quadratic trends or year fixed effects) yields consistent estimates since we have a panel with large $\mathrm{T}$.

\section{$3 \quad$ Static Estimates}

\subsection{Linear Specification}

Table 2 columns 1-3 and 5-7 shows the results of multivariate regressions of the nominal interest rate on 10-year government bonds, on the nominal interest rate on 3-month Treasury bills, the inflation rate, and the primary balance and public debt as a share of GDP. In columns 4 and 8 we also add the rate of growth of GDP among the rhs variables. The table shows that there is a positive relationship between the primary deficit as a share of GDP and the 10-year government bonds interest rate. Independently of the sample used and the control variables included in the estimation, the coefficient of the primary deficit is positive and statistically significant at the $5 \%$ level. The size of the coefficient, however, varies across specifications from 0.136 to 0.074 , implying that a one percentage point increase in the primary deficit to GDP ratio is associated with an increase of the 10-year government bonds interest rate from a maximum of 13.6 basis points to a minimum of 7.4 basis points.

On the other hand, in all but one specification (Table 2, column 4), we do not find a positive and statistically significant relationship between long-term interest rates and the stock of public debt as a share of GDP. In one specification (Table 2, column 1) the coefficient of $G D E B T 1$ is even negative and statistically significant, suggesting that a one percentage point increase in the stock of public debt as a share of GDP is associated with a decrease of one basis point of the 10-year government bonds interest rate.

\subsection{Non-linearities}

We are not the first ones to find evidence of a negative relation between the stock of public debt and long-term interest rates. Caporale and Williams (2002) interpret a negative coefficient as due to a portfolio effect. When governments issue bonds and investors consider them of high quality, they switch into them from bad quality debt. The price of such bonds goes differences of the right-hand side variables and allow for an $\operatorname{AR}(1)$ error term. Results are, however, very similar if one includes also one lag or one lead of the differences of the right-hand side variables among the regressors. 
up and the yield decreases. The opposite occurs when investors believe that governments' bonds are risky and of low quality. What this suggests is that the relation between long-term interest rates and the stock of public debt can be non-linear and depend, for example, on the level of the debt. When the stock of debt is low, financial markets consider it of high quality and an increase in its level is associated with a fall in interest rates. However, when government debt reaches a given threshold, further increases are associated with higher interest rates.

Following this line of argument, we investigate the presence of nonlinearities in Table 3. Columns 1 and 5 of Table 3 introduce among the regressors of Table 2 the square terms of the primary deficit and of the public debt to GDP ratios. We find evidence of non-linearities in the deficit in Sample $A$ but not in Sample B. Given that we tend to consider estimates from the latter sample more reliable because all variables included in the regression have the same order of integration, we do not put too much emphasis on this result. ${ }^{11}$ On the other hand, we find strong evidence of non-linearity in the public debt in both samples. An increase in the public debt-to-GDP ratio has a negative effect on long-term interest rates if the ratio is below $62.5 \%$ for the specification in column 1 and below $65.4 \%$ for the one in column 5. The effect of becomes positive when the debt-to-GDP ratio is above these thresholds values. Using the coefficients in column 1, a one standard deviation increase in the ratio of government debt to GDP (i.e. standard deviation of $G D E B T=0.26$ ) is associated with a decrease of the 10-year government bonds rate by 73 basis points when government debt is at its minimum value in sample (i.e. $G D E B T=0.12$ ) but with an increase by 94 basis points if the government debt is at its maximum value in sample (i.e. GDEBT =1.41).

Columns 2-4 and 6-8 check for non-linear variants to the simple quadratic term in columns 1 and 5. In particular, the idea is to see whether the relation between long-term interest rates and fiscal variables changes above a threshold level of the fiscal variables. To this end, we define two dummy variables, $D 1$ and $D 2$, equal to one if the primary deficitto-GDP ratio and, respectively, the public debt-to-GDP ratio are above their median values in the sample (and equal to zero otherwise). ${ }^{12}$ We then interact the dummy variables with the square of the difference between the primary deficit and its median value in the sample $\left(P R D E F-P R D E F^{*}\right)$, and the square of the difference between public debt and its median

\footnotetext{
${ }^{11}$ Tests results presented in section 2.1 suggested that all variables included in the specifications using Sample A, except GROWTH, are I(1) and cointegrated. GROWTH is, however, I(0).

${ }^{12}$ The median value of the primary deficit to GDP ratio is -0.001 in Sample A and 0.001 in Sample B. The median value of the government debt to GDP ratio is 0.59 in Sample $A$ and 0.61 in Sample B.
} 
value in the sample $\left(G D E B T-G D E B T^{*}\right)$. These experiments confirm that there is a clear nonlinearity in the size of the debt, while - at least in Sample B - the primary deficit continues to enter only linearly. Finally, in columns 3,4, 7, and 8 we check whether the effect of deficits depends on the level of debt and vice-versa. Results suggest that increases of the primary deficit to GDP ratio have a bigger and statistically significant effect (at the $10 \%$ level or better) on long-term interest rates when the public debt to GDP ratio is above its median value. Instead, we find evidence that the effect of public debt on interest rates depends on the level of the primary deficit in Sample A, but not in Sample B.

\subsection{Instrumental Variables}

Table 4 addresses the potential endogeneity between long-term interest rates and the public debt. A shock to the long-term interest rate can influence the stock of public debt by increasing interest expenses. ${ }^{13}$ Both to address this specific source of endogeneity, and to assuage concerns about additional omitted variables, in this table we estimate the models considering all the regressors as endogenous. For presentation reasons, we also show IV estimates for Sample A, but we focus on estimates for Sample B. In fact, based on the results in Table 1 on the time series properties of the data, IV estimates are correct only when Sample $B$ is used. Columns 1, 2, 5, and 6 present results for a just identified model where all variables are instrumented by their first lag. In columns 3 and 7, we instrument the rhs variables with their first and second lag, while in columns 4 and 8 we use only the second lag of the regressors and of the left-hand side variable as instruments. The estimates of the coefficients and their standard errors are very similar to the ones obtained when we estimate models by DGLS or OLS.

\footnotetext{
${ }^{13}$ In pricinciple, the 10 -year interest rate can also affect the primary deficit by inducing policy makers to implement changes in their spending and tax revenues' programs. Note, however, that the budget for the current year is approved during the second half of the previous year and, even though additional measures can be taken during the course of the year, they usually become effective with some delay. Hence, the primary deficit is much less likely to be an endogenous variable than the stock of public debt. Furthermore, this type of endogeneity would likely bias our results towards finding lower coefficients, as - if anything policymakers' response to higher rates will be to tighten the budget.
} 


\section{4 "World" fiscal policy}

Another important issue to be examined is the impact of fiscal policy at the world level. If economies are open and fully integrated with no barriers to trade or capital mobility, if governments borrow in a common currency, and if governments' default risks are negligible, the real interest rate in each country should depend only on measures of worldwide aggregate fiscal policy, not on indicators of fiscal policy in an individual country. From the individual country's standpoint, fiscal expansion is reflected primarily in a widening of the external current account deficit and possibly a change in the exchange rate. In the simplest case, an individual country's fiscal policy affects the interest rates it faces only to the extent that it is affects the worldwide macroeconomic balance - i.e. it would be only the "world" primary deficit and "world" debt that matter. However, this simple theoretical result could break down for a number of reasons: for instance, if capital mobility is limited; if goods market mobility is limited (e.g. in cases in which exchange rate movements are associated with changes in the relative price of tradables); if current fiscal deficits are expected to be financed partly through domestic inflation; or if the risk of government default is non-negligible.

It therefore seems desirable to examine empirically the hypothesis that an individual country's fiscal variables affects the real interest rate only to the extent that they influence "world" aggregate variables. To do this with the existing data set, we use average values across OECD countries of the right-hand side variables as a proxy for "world" variables. An obvious caveat is that the OECD is not, in fact, the world: it omits a sizable part of the world economy which may have substantial aggregate savings. At the same time, OECD aggregates do cover a substantial part of the world economy - and an even larger share of global financial markets.

We construct "world" variables for each regressor and introduce these "world" indices among the rhs variables. In columns 1, 2, 5, and 6 of Table 5 , a "world" variable is equal to the weighted average of the variable across all countries in the sample. Weights are based on shares of real GDP measured in PPP terms. ${ }^{14}$ Note that the "world" variables constructed in this way have a common value across all countries in the panel. For this reason, year dummies cannot be included as controls in the empirical specifications in columns 1, 2, 5, and 6 of Table 5.

We estimate the models of Table 5, columns 1, 2, 5, and 6, including a common linear

\footnotetext{
${ }^{14}$ That is, we weight the value of the variable for country $i$ in year $t$ by the share of country $i$ 's real GDP in the aggregate real GDP of the countries in the sample.
} 
and quadratic trend among the regressors. Results are quite interesting. First, contrary to the evidence on short-term real interest rates in Barro and Sala-i-Martin (1990), we find that both "world" fiscal policy variables and an individual country's fiscal variables matter for long-term interest rates. The magnitude of the coefficients of the "world" primary deficit and "world" public debt are sizeable. An increase by one percentage point of WPRDEF leads to an increase in the interest rate of 10-year government bonds from a minimum of 28 basis points to a maximum of 66 basis points, and an increase by the same amount of $W G D E B T$ raises interest rates from a minimum of 3 basis points of a maximum of 21 basis points. The coefficients are statistically significant at conventional critical values. Importantly, however, the size and the significance of the coefficients of PRDEF, GDEBT, and GDEBT ${ }^{2}$ are virtually unchanged from the evidence in the previous tables. Note also that results in Table 5 columns 1, 2, 5, and 6 do not change when we allow the linear and quadratic trend to be country specific. This implies that little if any of the impact of domestic deficits estimated in the panel regressions reported earlier is channelled via the world economy. ${ }^{15}$

An alternative formulation is to construct a "rest of the world" (ROW) average variables that complement the individual country variables. This permits us to include year fixed effects among the regressors and check that the evidence presented so far still holds. Results with this formulation are reported in columns 3, 4, 7, and 8. Consistently with our previous results, individual countries' changes in the primary deficit to GDP ratio has always a positive and statistically significant effect on $I N T 10 Y$, while the effect of public debt is positive (negative) when public debt is above (below) a given threshold. As for the effect of the "world" policy indicators, the coefficient of the average value of the primary deficit

\footnotetext{
${ }^{15}$ We also investigated the existence of structural breaks for euro countries in 1999. In particular, for the Euro-zone economies, one might expect that: (i) indicators of fiscal policy in individual countries influence national interest rates before 1999 but not after, (ii) measures of aggregate fiscal policy are the only ones that matter after 1999. To test (i) and (ii), we defined a dummy variable PEMU equal to 1 after 1999 for the countries in our panel that adopted the euro (Austria, Belgium, Germany, Spain, France, Ireland, Italy, the Netherlands) and equal to zero otherwise. We interacted the variable $P E M U$ with the variables $P R D E F, G D E B T 1$ or GDEBT2 and their square and with WPRDEF and WGDEBT. We estimated columns 1 and 5 of Table 5 including these additional variables among the regressors. We also estimated these specifications eliminating the square of the variables. We did not find significant and robust evidence that suggests the presence of a structural break in the relative importance of national and world fiscal policy variables before and after 1999. However, we also think that our experiment is not conclusive. There are at least two caveats that one has to consider. First, the set of countries of the European Union that potentially could have adopted the euro is different from the one that ended up adopting the euro. Second, 1999 cannot be the right date to identify the break if, for example, financial markets anticipated the adoption of the euro.
} 
is no longer significant, while the one of public debt is still positive and significant and its value ranges from 0.096 to 0.115 . In conclusion, we read the results in Table 5 as evidence in favor of the international financial integration among OECD countries and the possibility that fiscal shocks in one country influences interest rates in others. However, it seems that either the degree of integration is far from perfect, or that there is a non-negligible risk that deficits are reflected in expected inflation or default risk: changes in the domestic stance of fiscal policy still matter for domestic long-term interest rates beyond their effect on aggregate variables.

\subsection{Financial Development}

In this section we bring into the picture indicators of financial development. The rationale for this extension is twofold. First, financial development obviously potentially affects the level of interest rates, and if it is correlated with fiscal policy it may generate a bias in our coefficients. This suggests that it is worthwhile to include financial development as an additional control. Second, the degree of financial development may affect the responsiveness of interest rates to fiscal shocks. This suggests that it may be interesting to include interactions among the fiscal variables and financial development. The range of financial development in this OECD sample is comparatively limited; but even within this set of developed countries, differences in the financial systems, and in the depth and liquidity of financial markets, can have important effects on the behavior of long-term interest rates.

We add among the regressors the variables used by Levine et al. (2000) to measure financial liberalization. Specifically, we use the variable LIQUID LIABILITIES equal to the liquid liabilities of the financial system as a share of GDP, the variable PRIVATE $C R E D I T$, equal to the value of credits by financial intermediaries to the private sector divided by GDP, and the indicator COMMERCIAL - CENTRAL BANK, equal to the ratio of commercial banks assets divided by commercial bank plus central bank assets. In Table 6 we show the results obtained when we add the first of the three variables. An increase in financial liberalization leads to a decrease in the long-term interest rate and the coefficient of LIQUID LIABILITIES is statistically significant at the $5 \%$ level. More to the point for our purposes, the effect of changes in the primary deficit and public debt to GDP ratio remains virtually unchanged. Results (not shown) are along the same line if we measure financial development with the variables PRIVATE CREDIT and COMMERCIAL CENTRAL BANK. 
More interesting results are obtained by adding interaction terms between the fiscal variables and financial development. Here, we find that the degree of financial development affects the responsiveness of interest rates to changes in the primary-deficit-to GDP ratio: in more developed financial markets, increases in the primary deficit-to-GDP ratio attenuate the surge in long-term interest rates.

\subsection{Alternative left-hand-side variables}

We conclude this section by discussing the results we obtain by using a variety of alternative left-hand-side variables.

We have re-estimated the relation between interest rates, the inflation rate, fiscal variables and GDP growth using real rather than nominal interest rates. Ideally, one would like to measure the long term real interest rate as the difference between the 10-year nominal interest rate and expectations of inflation of the next ten years. Inflation's forecasts over such a long-term time period are not available for our panel of countries. We follow Orr et al. (1995) in proxying long-term inflation expectations by trend inflation. ${ }^{16}$ Our results (shown in Table 7) are almost unchanged relatively to the ones in the specifications using nominal interest rates.

Second, we use as the dependent variable the nominal yield spread of 10-year government bonds over 3-month Treasury bills. Once again, as Table 8 shows, our conclusions on the effect of fiscal policy on long-term interest rates are unaffected by this specification change. Third, we use as our left-hand side variable the long-term interest rate series published by the OECD, which is an average of the interest rates paid on long-term government bonds. Fourth, we look at the spread between domestic 10 year interest rates and German 10 year interest rates. Again results (not shown but available upon request) still hold. One popular left-hand-side variable in studies of the effect of fiscal variables is the yield spread of 10-year government bonds over swap contracts with the same maturity and currency denomination. ${ }^{17}$ The rationale for this choice of dependent variable is that it measures the

\footnotetext{
${ }^{16}$ We compute trend inflation using the Hodrick-Prescott filter. We apply the filter to each country inflation rate using quarterly data and a value of $\lambda$ equal to 1600 . We then take the average over each year of the trend inflation generated with quarterly data and calculate the 10-year real interest rate at a yearly frequency by subtracting the average of trend inflation to the nominal interest rate. We also start with quarterly data to compute the real 3-month interest rate as the difference between the nominal interest rate of 3-month Treasury bills and the ex-post inflation rate. We then average over the year the quarterly data.

${ }^{17}$ Swap contracts are agreements to exchange a flow of interest rates payments at a fixed rate for one at
} 
government's default risk. In Table 9, we show that fiscal policy also affects the 10-year interest rate on swap contracts, which implies that fiscal policy shocks affect interest rates also on instruments not issued by the government. In fact, if we use as our left-hand side variable the spread of the 10-year government bond interest rate over the swap interest rate we find that the coefficients of $P R D E F$ and $G D E B T$ are not statistically significant. These results may suggest that the impact of fiscal policy on interest rates is not likely to be via default risk directly, but could be through expected inflation (which can also be triggered by an increase in sovereign default risk), or through the demand for loanable funds, both of which would be expected to affect the swap market in a similar way to the long-term bond market. $^{18}$

\section{Dynamic Estimates}

So far, our analysis has not allowed for the fact that financial markets are forward-looking and, hence, react not only to fiscal shocks in the current period, but also to the expectation of future fiscal policy. Moreover, coefficients in tables shown so far do not capture the full impact of changes in fiscal policy on long-term interest rates, because we have not accounted for the effects that fiscal variables have on long-term rates through their potential influence on the short-term rate, the inflation rate and the rate of growth of GDP.

In this section, we attempt to address these issues by estimating a vector autoregressive system including the 10-year government bonds interest rate, the 3 -month Treasury bills interest rate, the inflation rate, the rate of growth of GDP, the primary deficit-to-GDP ratio and the public debt-to-GDP ratio. We set the lag length of the system to 2 and, following Alesina et al. (2002), we estimate the VAR on the entire panel. ${ }^{19}$ We then study the impulse response function of the long-term interest rate to a shock to the primary deficit or public debt at the time of the shock and in the following years. ${ }^{20}$

a floating rate. For papers that use the interest rate of swap contracts to measure governments' default risk see, for example, Afonso and Strauch (2003), Bernoth et al. (2003), Codogno et al. (2003), Favero et al. (1997), and Lemmen and Goodhart (1999).

${ }^{18}$ Data on swap contracts are not available before 1988 for countries in our sample. For this reason, we present only estimates with Sample $B$ in Table 9.

${ }^{19}$ To estimate the VAR, we demean the data from country and year averages to control for country and time fixed effects.

${ }^{20}$ Gale and Orszag (2002) note that studies that do not take expectations into account are biased toward finding no effect because they do not account for the fact the financial markets are forward-looking. Also, 
In order to obtain meaningful impulse responses of the long-term rate to the fiscal shock, we need innovations that are mutually orthogonal. The reduced form innovations are clearly correlated with each other and a shock to the primary deficit (public debt) is not really a shock to this variable but a linear combination of its structural shock and shocks of the other variables included in the system. To identify the structural primary deficit and public debt shocks, we use the Cholesky decomposition, and we orthogonalize the innovations in several ways to check that our results are not unduly sensitive to the order with which we choose variables to enter the system.

We consider two extreme cases. First, we assume that fiscal policy variables "come first", followed by the inflation rate, the rate of growth of GDP, the 3-month Treasury bills interest rate and the 10-year government bonds interest rate (Table 10, parts Ia and Ib). Second, we consider the case in which $I N T 3 M$ is ordered first, followed by INFL, GROWTH, PRDEF, GDEBT, and INT10Y (Table 10, parts IIa and IIb). Within each case, we consider both the sub-case with the primary deficit "coming before" public debt (Table 10 parts Ia and IIa) and the sub-case with public debt "coming before" the primary deficit (Table 10 parts Ib and IIb). We also checked (and confirm) that results are similar to the ones in Table 10 when we exchange the order of INFL and GROWTH. ${ }^{21}$

Table 10 displays the changes in the 10-year government bond interest rate following a shock to the primary deficit and public debt by one percentage point, on impact and up to ten years, and the cumulative change after the first five and ten years.

A positive shock to the ratio of primary deficit to GDP leads to an increase in $I N T 10 Y$ of 7 basis points on impact, and to a cumulative increase of 66 and 146 basis points after five works based on time series evidence from the US that measures expectations through a vector autoregression tend to find smaller and less robust effects than studies that include measures of forecasted fiscal variables from the Congressional Budget Office (CBO) or the Office of Management and Budget (OMB). While forecasts from a VAR are based only on past information on variables of the system, forecasts from the $\mathrm{CBO}$ or the OMB also use other information as, for example, information on proposed changes in tax and spending legislation.

To the best of our knowledge, long-horizon forecasts of future fiscal policy variables are not available for our large panels. Renhart and Sack (2000) use the budget surplus forecasted for the following year by the OECD from 1981 onwards. But we find no study using panel data on OECD countries that includes 5-year ahead and/or 10-year ahead projections of the deficit and the public debt. Hence, we cannot follow the literature on the US (see for example Canzoneri, Cumby and Diba (2002), and Laubach (2003)) and we can only account for expectations estimating a VAR system.

${ }^{21}$ The use of yearly data prevents us from adopting the identification assumptions in Blanchard and Perotti (2002), and Perotti (2002). 
and ten years, respectively (see Part I of Table 10). The impact effect is very similar to the one we obtain in the static models, but since the effect persists over time, the cumulative response of the long-term interest rate after five and ten years is quite sizeable. This provides evidence in line with Feldstein (1986) who emphasizes the importance of considering expectations about the stance of future fiscal policy in measuring the effect of the government deficit on interest rates. The coefficients are statistically significant at the $5 \%$ level.

Increases in public debt, in general, lead to lower interest rates on impact and in a few years after the shock occurs. However, the effect becomes positive as time goes by and the cumulative response ten years after the shock is often positive and statistically significant. In line with the results from the static models, the magnitude of the effects is smaller than the one due to a change in the primary deficit. Finally, note that, while the response of INT $10 Y$ to a shock to the primary deficit is not unduly sensitive to the orthogonalization procedure, the coefficients of GDEBT are quite different in size according to the strategy used to identify the structural shocks. This consideration calls for considerable caution in interpreting these dynamic results.

\section{Conclusions}

This paper has used cross-country empirical analysis to establish that fiscal deficits and the accumulated public debt affect interest rates. The effects are both statistically and economically significant, and they are robust to a variety of specifications. These effects are non-linear, becoming stronger as a country's debt grows and its fiscal balance becomes weaker. The dynamic analysis presented also shows that the long-run effects of sustained deficits are much larger than the immediate impact of a one-time deficit. These results imply that the return to fiscal laxity that has taken place in several major industrial countries in recent years is potentially worrisome.

Fiscal policy has important effects at the worldwide level, but it also has important

effects at the level of the individual country. These results suggest that, while each country's fiscal imbalance has its greatest impact at home, it is also a legitimate concern at the level of the world economy. 


\section{References}

[1] Afonso A, and R. Strauch, (2003), "Fiscal Policy Events and Interest Rate Swaps Spreads: some Evidence from EU", European Central Bank working paper.

[2] Alesina A., M. de Broeck, A. Prati, and G. Tabellini, (1992), "Default Risk on Government Debt in OECD Countries", Economic Policy, October, 15, pp.427-463.

[3] Bandiera O., G. Caprio, P. Honohan, F. Schiantarelli, (1999), "Does Financial Reform Raise or Reduce Saving?" The Review of Economics and Statistics, May 2000, 82(2), pp. 239-263.

[4] Barro R., and X. Sala-i-Martin, (1990), "World Real Interest Rates." NBER Macroeconomics Annual, MIT Press, (Cambridge, MA), pp. 15-74.

[5] Barro R., (1987), "Government Spending, Interest Rates, Prices, and Budget Deficits in the United Kingdom, 1701-1918", Journal of Monetary Economics, vol. 20, no. 2, pp. 221-247.

[6] Barth J., G. Iden, F. Russek, and M. Wohar, (1991), "The effects of Federal budget Deficits on Interest Rates and the Composition of Domestic Output", in The Great Fiscal Experiment, edited by Rudolph G. Penner. Washington: Urban Institute Press.

[7] Bernoth K., J. Von Hagen, L. Schuknecht, (2003), "The Determinants of the Yield Differential in the EU Government Bond Market", European Central Bank working paper.

[8] Blanchard O, R. Perotti, (2002), "An Empirical Characterization of the Dynamic Effects of Changes in Government Spending and Taxes on Output", Quarterly Journal of Economics, vol. 117, n.4, pp. 1329-1368.

[9] Blanchard O., and L. Summers, (1984), "Perspective on High World Real Interest Rates", Brookings Papers on Economic Activity, vol. 1984, n. 2, pp. 273-324.

[10] Canzoneri M., R. Cumby, and B. Diba, (2002), "Should the European Central Bank and the Federal Reserve Be Concerned About Fiscal Policy", in Rethinking Stabilization Policy", A Symposium Sponsored by the Federal Reserve Bank of Kansas City, pp. 333389. 
[11] Caporale G., and G. Williams, (2002), "Long-term nominal Interest Rates and Domestic Fundamentals", Review of Financial Economics, vol. 11, pp. 119-130.

[12] Codogno L., C. Favero, A. Missale, (2003), "Yield Spreads on EMU Government Bonds", Economic Policy, October 2003, pp. 503-532.

[13] Evans P., (1985), "Do Large Deficits Produce High Interest Rates?" American Economic Review, vol. 75, n.1, pp. 68-87

[14] Evans P., (1987), "Do Budget Deficits Raise Nominal Interest Rates? Evidence From Six Countries", Journal of Monetary Economics, 20, pp. 281-300.

[15] Favero C., F. Giavazzi, and L. Spaventa, (1997), "High Yields: The Spread on German Interest Rates", Economic Journal, 107, July, pp. 956-985.

[16] Feldstein M, (1986), "Budget Deficits, Tax rules, and Real Interest Rates", National Bureau of Economic Research, working paper no. 1970.

[17] Gale W., and P. Orszag, (2002), "The Economic Effects of Long-Term Fiscal Discipline", Brookings Institution.

[18] Hoelscher G, (1986), "New Evidence on Deficits and Interest Rates", Journal of Money Credit, and Banking, vol. 18, n. 1, pp. 1-17.

[19] Im K., H. Pesaran, and Y. Shin, (2002), "Testing for Unit Roots in Heterogeneous Panels".

[20] Laubach T., (2003), "New Evidence on the Interest Rate Effects of Budget Deficits and Debt", Board of Governors of the Federal Reserve System.

[21] Lemmen J., and C. Goodhart, (1999), "Credit Risks and European Government Bond Markets: A Panel Data Econometric Analysis", Eastern Economic Journal, vol. 25, n.1, Winter 1999.

[22] Levine R., Loayza N., and B. Thorsten, (2000), "Financial Intermediation and Growth", Journal of Monetary Economics, n.46, pp. 31-77.

[23] Mark N., Sul D., (2002), "Cointegration Vector Estimation by Panel DOLS and LongRun Money Demand", National Bureau of Economic Research, technical working paper no. 287. 
[24] Miller S., and F. Russek, (1991), "The Temporal Casuality between Fiscal Deficits and Interest Rates", Contemporary Policy Issues, vol. ix, July 1991, pp. 12-23.

[25] Miller S., and F. Russek, (1996), "Do Federal Deficits Affect Interest Rates? Evidence from Three Econometric Methods", Journal of Macroeconomics, Summer 1996, vol. 18, n.3, pp. 403-428.

[26] Mountford A., H. Uhlig, (2000), "What are the Effects of Fiscal Policy Shocks", Centre for Economic Policy research, October.

[27] Paesani P., R. Strauch, (2003), "Public Finances and Long-term interest rates: Linkages between Europe and the USA", European Central Bank.

[28] Pedroni P., (1999), "Critical Values for Cointegration Tests in heterogeneous Panels with Multiple Regressors", Oxford Bulletin of Economics and Statistics, vol. 61, no. 4, pp 653-670.

[29] Perotti R., (2002), "Estimating the Effects of Fiscal Policy in OECD Countries", ISOM conference, Frankfurth, June 2002.

[30] Plosser C., (1987), "Fiscal Policy and the Term Structure", Journal of Monetary Economics, 20, pp. 343-367.

[31] OECD Economic Outlook n.73, June 2003.

[32] Orr A., M. Edey, and M. Kennedy, (1995), "The Determinants of Real Long-Term Interest Rates: 17 Country Pooled-Time-Series Evidence" OECD working paper no. 155.

[33] Reinhart V., B. Sack, (2000), "The Economic Consequence of Disappearing Government Debt", Brookings Papers on Economic Activity, vol. 2, pp. 163-209.

[34] Stock J., and M. Watson, (1993), "A Simple Estimator of Cointegrating Vectors in Higher Order Integrated Systems", Econometrica, 91, pp. 783-820.

[35] Tavares J., and R. Valkanov, (2001), "The Neglected Effect of Fiscal Policy on Stock and Bond Returns". 


\section{Part I: Integration Tests ${ }^{1}$}

\section{INT10Y}

1.38

$-3.13^{*}$
INT3M

INFL

$-1.63$

$-3.13^{*}$
$-2.75 *$
PRDEF

$-1.60$

$-1.70 *$
GDEBT1

GDEBT 2

Sample 1960-2002

Sample 1975-2002

art II: Cointegration Tests

ADF t-test

\section{Panel ADF}

Sample 1960-2002
0.56

$-3.34 *$

$2.66^{*}$

\section{Notes:}

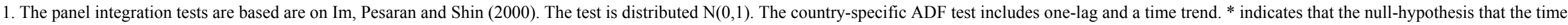
series is I(1) is rejected at the $5 \%$ level.

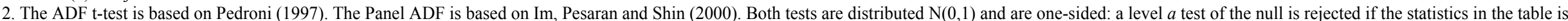

$<z_{a}$ where $z_{a}$ is the $a$ standard normal quantile. * indicates that the null-hypothesis that variables are not cointegrated is rejected at the $5 \%$ level. Cointegrating vector: INT10Y, INT3M, INFL, PRDEF, GDEBT

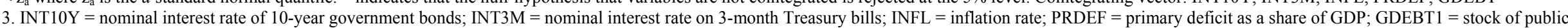

debt measured at the end of period $t-1$ divided by the level of GDP in year t-1; GDBET2 = average of the stock of public debt in year $t-1$ and in year $t$ divided by GDP in year $t$. 


\begin{tabular}{|c|c|c|c|c|c|c|c|c|}
\hline & \multicolumn{4}{|c|}{$\begin{array}{l}\text { Dep. var. INT10Y } \\
\text { Sample 1960-2002 }\end{array}$} & \multicolumn{4}{|c|}{$\begin{array}{l}\text { Dep. var. INT10Y } \\
\text { Sample 1975-2002 }\end{array}$} \\
\hline & (1) & (2) & (3) & (4) & (5) & (6) & (7) & (8) \\
\hline & DGLS & DGLS & DGLS & DGLS & OLS & OLS & OLS & OLS \\
\hline \multirow[t]{2}{*}{ INT3M } & 0.629 & 0.524 & 0.389 & 0.390 & 0.647 & 0.521 & 0.436 & 0.443 \\
\hline & $(29.48)^{* *}$ & $(23.57)^{* *}$ & $(13.34)^{* *}$ & $(13.49)^{* *}$ & $(25.03)^{* *}$ & $(14.64)^{* *}$ & $(11.74)^{* *}$ & $(12.23)^{* *}$ \\
\hline \multirow[t]{2}{*}{ INFL } & 0.127 & 0.120 & 0.128 & 0.141 & 0.146 & 0.149 & 0.160 & 0.168 \\
\hline & $(5.57)^{* *}$ & $(7.96)^{* *}$ & $(5.93)^{* *}$ & & $(5.53)^{* *}$ & $(5.06)^{* *}$ & $(6.36)^{* *}$ & $(6.71)^{* *}$ \\
\hline \multirow[t]{2}{*}{ PRDEF } & 0.128 & 0.113 & 0.106 & 0.101 & 0.136 & 0.109 & 0.074 & 0.081 \\
\hline & $(4.79)^{* *}$ & $(5.37)^{* *}$ & $(5.05)^{* *}$ & $(5.06)^{* *}$ & $(5.90)^{* *}$ & $(4.86)^{* *}$ & $(3.79)^{* *}$ & $(4.08)^{* *}$ \\
\hline \multirow[t]{2}{*}{ GDEBT } & -0.010 & -0.005 & -0.0001 & 0.006 & 0.0001 & 0.003 & 0.002 & 0.005 \\
\hline & $(-2.64)^{* *}$ & $(-1.53)$ & $(-0.04)$ & $(1.79)^{*}$ & $(0.04)$ & $(0.87)$ & $(0.66)$ & $(1.48)$ \\
\hline \multirow[t]{2}{*}{ GROWTH } & & & & 0.143 & & & & 0.082 \\
\hline & & & & $(5.42)^{* *}$ & & & & $(2.81)^{* *}$ \\
\hline Country Dummies & Yes & Yes & Yes & Yes & Yes & Yes & Yes & Yes \\
\hline Trend and Trend ${ }^{2}$ & No & Yes & No & No & No & Yes & No & No \\
\hline Year Dummies & No & No & Yes & Yes & No & No & Yes & Yes \\
\hline Adjusted $\mathbf{R}^{2}$ & & & & & 0.90 & 0.92 & 0.94 & 0.94 \\
\hline N. of obs. & 413 & 413 & 413 & 413 & 373 & 373 & 373 & 373 \\
\hline
\end{tabular}

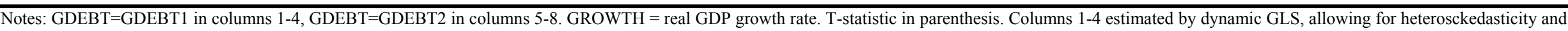

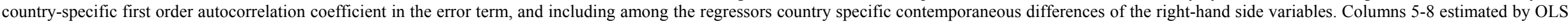
and T-statistics are corrected for heterosckedasticity. See also notes to Table 1. 


\begin{tabular}{|c|c|c|c|c|c|c|c|c|}
\hline & \multicolumn{4}{|c|}{$\begin{array}{l}\text { Dep. var. INT10Y } \\
\text { Sample 1960-2002 }\end{array}$} & \multicolumn{4}{|c|}{$\begin{array}{l}\text { Dep. var. INT10Y } \\
\text { Sample 1975-2002 }\end{array}$} \\
\hline & (1) & (2) & (3) & (4) & (5) & (6) & (7) & (8) \\
\hline & DGLS & DGLS & DGLS & DGLS & OLS & OLS & OLS & OLS \\
\hline \multirow[t]{2}{*}{ INT3M } & 0.387 & 0.391 & 0.384 & 0.374 & 0.449 & 0.450 & 0.444 & 0.457 \\
\hline & $(14.55)^{* *}$ & $(14.91)^{* *}$ & $(14.29)^{* *}$ & $(13.91)^{* *}$ & $(12.58)^{* *}$ & $(12.59)^{* *}$ & $(12.43)^{* *}$ & $(12.48)^{* *}$ \\
\hline \multirow[t]{2}{*}{ INFL } & 0.156 & 0.168 & 0.161 & 0.189 & 0.173 & 0.171 & 0.174 & 0.168 \\
\hline & $(7.49)^{* *}$ & $(8.49)^{* *}$ & $(8.31)^{* *}$ & $(9.59)^{* *}$ & $(7.13)^{* *}$ & $(6.92)^{* *}$ & $(6.99)^{* *}$ & $(6.74)^{* *}$ \\
\hline \multirow[t]{2}{*}{ PRDEF } & 0.116 & 0.095 & 0.126 & 0.036 & 0.093 & 0.105 & 0.142 & 0.127 \\
\hline & $(5.54)^{* *}$ & $(3.43)^{* *}$ & $(3.94)^{* *}$ & (1.19) & $(4.38)^{* *}$ & $(3.73)^{* *}$ & $(4.00)^{* *}$ & $(3.64)^{* *}$ \\
\hline \multirow[t]{2}{*}{ GDEBT } & -0.030 & -0.007 & -0.009 & -0.004 & -0.017 & -0.001 & -0.004 & -0.002 \\
\hline & $(-3.80) * *$ & $(-1.62)$ & $(-2.15)^{* *}$ & $(-1.07)$ & $(-1.50)$ & $(-0.29)$ & $(-0.79)$ & $(-0.33)$ \\
\hline \multirow[t]{2}{*}{ GROWTH } & 0.124 & 0.139 & 0.127 & 0.156 & 0.087 & 0.086 & 0.088 & 0.087 \\
\hline & $(4.75)^{* *}$ & $(5.48)^{* *}$ & $(5.20)^{* *}$ & $(6.14)^{* *}$ & $(2.86)^{* *}$ & $(2.84)^{* *}$ & $(2.91)^{* *}$ & $(2.87)^{* *}$ \\
\hline \multirow[t]{2}{*}{ PRDEF $^{2}$} & 0.813 & & & & -0.140 & & & \\
\hline & $(2.55)^{* *}$ & & & & $(-0.37)$ & & & \\
\hline \multirow[t]{2}{*}{ GDEBT $^{2}$} & 0.024 & & & & 0.013 & & & \\
\hline & $(5.62)^{* *}$ & & & & $(1.99)^{* *}$ & & & \\
\hline \multirow[t]{2}{*}{$\left(\text { PRDEF- PRDEF }^{*}\right)^{2} *$ D1 } & & 0.950 & -1.303 & 1.328 & & -0.454 & -1.802 & -0.615 \\
\hline & & $(2.10)^{* *}$ & $(1.62)$ & $(2.90)^{* *}$ & & $(-0.79)$ & $(-1.57)$ & \\
\hline \multirow[t]{2}{*}{$\left(G D E B T-G D E B T^{*}\right)^{2} * D 2$} & & 0.030 & 0.029 & 0.019 & & 0.013 & 0.015 & 0.019 \\
\hline & & $(4.86)^{* *}$ & $(5.31)^{* *}$ & $(2.92)^{* *}$ & & $(1.65)^{*}$ & $(1.83)^{*}$ & $(2.18)^{* *}$ \\
\hline \multirow[t]{2}{*}{$\left.(\text { PRDEF- PRDEF })^{*}\right)^{*}$ D2 } & & & 1.980 & & & & 1.234 & \\
\hline & & & $(3.71)^{* *}$ & & & & $(1.65)^{*}$ & \\
\hline \multirow[t]{2}{*}{$\left(G^{2} B B T-G D E B T^{*}\right)^{2} * D 1$} & & & & 0.029 & & & & -0.013 \\
\hline & & & & $(3.43)^{* *}$ & & & & $(-1.29)$ \\
\hline N. of obs. & 413 & 413 & 413 & 413 & 373 & 373 & 373 & 373 \\
\hline
\end{tabular}

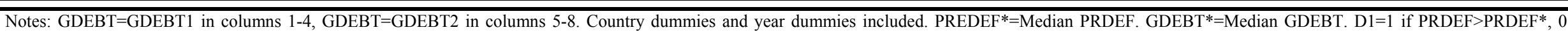

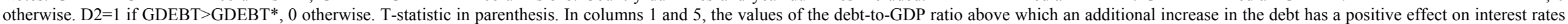
are $62.5 \%$ and $65.4 \%$ respectively. See also notes to Tables 1 and 2 . 


\begin{tabular}{|c|c|c|c|c|c|c|c|c|}
\hline & \multicolumn{4}{|c|}{$\begin{array}{l}\text { Dep. var. INT10Y } \\
\text { Sample 1960-2002 }\end{array}$} & \multicolumn{4}{|c|}{$\begin{array}{l}\text { Dep. var. INT10Y } \\
\text { Sample 1975-2002 }\end{array}$} \\
\hline & (1) & (2) & (3) & (4) & $(5)$ & (6) & (7) & (8) \\
\hline & IV & IV & IV & IV & IV & IV & IV & IV \\
\hline \multirow[t]{2}{*}{ INT3M } & 0.352 & 0.391 & 0.356 & 0.621 & 0.349 & 0.387 & 0.327 & 0.539 \\
\hline & $(4.42)^{* *}$ & $(4.92)^{* *}$ & $(4.58)^{* *}$ & $(3.62)^{* *}$ & $(4.63)^{* *}$ & $(4.89)^{* *}$ & $(5.16)^{* *}$ & $(3.72)^{* *}$ \\
\hline \multirow[t]{2}{*}{ INFL } & 0.308 & 0.310 & 0.303 & 0.288 & 0.320 & 0.321 & 0.279 & 0.292 \\
\hline & $(4.48)^{* *}$ & $(4.80)^{* *}$ & $(4.82)^{* *}$ & $(2.22)^{* *}$ & $(4.65)^{* *}$ & $(4.87)^{* *}$ & $(4.79)^{* *}$ & $(2.46)^{* *}$ \\
\hline \multirow[t]{2}{*}{ PRDEF } & 0.049 & 0.107 & 0.071 & 0.158 & 0.070 & 0.108 & 0.068 & 0.161 \\
\hline & $(1.91)^{*}$ & $(3.68)^{* *}$ & $(2.76)^{* *}$ & $(2.87)^{* *}$ & $(2.84)^{* *}$ & $(3.86)^{* *}$ & $(2.90)^{* *}$ & $(2.87)^{* *}$ \\
\hline \multirow[t]{2}{*}{ GDEBT } & 0.002 & -0.043 & -0.033 & -0.070 & 0.002 & -0.035 & -0.020 & -0.064 \\
\hline & $(0.41)$ & $(-3.10)^{* *}$ & $(-2.30)^{* *}$ & $(-3.11)^{* *}$ & $(0.45)$ & $(-2.24)^{* *}$ & $(-1.44)$ & $(-2.61)^{* *}$ \\
\hline \multirow[t]{2}{*}{ GROWTH } & -0.119 & -0.048 & -0.025 & 0.101 & -0.082 & -0.043 & -0.055 & -0.229 \\
\hline & $(-1.07)$ & $(-0.44)$ & $(-0.25)$ & $(0.41)$ & $(-0.74)$ & $(-0.38)$ & $(-0.62)$ & $(-0.86)$ \\
\hline \multirow[t]{2}{*}{ PRDEF $^{2}$} & & -1.312 & -0.397 & -3.120 & & -1.123 & 0.270 & -3.261 \\
\hline & & $(-1.50)$ & $(-0.53)$ & $(-1.55)$ & & $(-1.26)$ & $(0.38)$ & $(-1.30)$ \\
\hline \multirow[t]{2}{*}{ GDEBT $^{2}$} & & 0.030 & 0.024 & 0.049 & & 0.023 & 0.013 & 0.040 \\
\hline & & $(3.74)^{* *}$ & $(2.94)^{* *}$ & $(3.90)^{* *}$ & & $(2.56)^{*}$ & $(1.64)^{*}$ & $(2.96)^{* *}$ \\
\hline N. of obs. & 413 & 413 & 399 & 393 & 367 & 367 & 360 & 357 \\
\hline
\end{tabular}

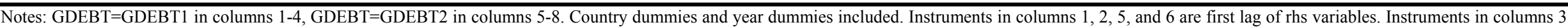

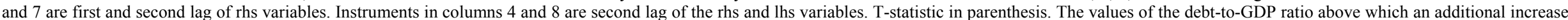
in the debt has a positive effect on interest rates are $71.7 \%, 68.7 \%, 71.4 \%$ in columns $2-4$, and $76.1 \%, 76.9 \%, 80 \%$ in columns $6-8$. See also notes to Tables 1 and 2 . 


\section{INT3M}

INFL

\section{PRDEF}

\section{GDEBT}

\section{GROWTH}

\section{PRDEF $^{2}$}

GDEBT $^{2}$

WINT3M

\section{WINFL}

\section{WPRDEF}

\section{WGDEBT}

\section{WGROWTH}

\section{Trend and Trend ${ }^{2}$}

\section{Year Dummies}

\section{N. of obs.}

\section{Dep. var. INT10Y}

\section{Sample 1960-2002}

(1)

DGLS

IV

(3)

DGLS

(4)

IV

\subsection{4}

$(12.23)^{* *}$

0.176

$(7.03)^{* *}$

0.134

$(4.99)^{* *}$

$-0.051$

$(-5.66)^{* *}$

0.105

$(3.31)^{* *}$

$-0.105$

$(-0.28)$

0.036

$(6.74)^{* *}$

0.597

$(12.21)^{* *}$

0.066

(1.19)

0.282

$(3.68)^{* *}$

0.031

(1.46)

0.244

$(3.30)^{* *}$

Yes
0.367

$(3.67)^{* *}$

0.322

$(3.91)^{* *}$

0.118

$(3.07)^{* *}$

$-0.052$

$(-2.49)^{* *}$

$-0.050$

$(-0.39)$

$-1.142$

(-1.05)

0.034

$(3.00)^{* *}$

0.751

(1.63)

$-0.125$

$(-0.58)$

0.657

$(2.35)^{* *}$

0.088

(1.77)*

0.554

(0.81)

Yes

\subsection{4}

$(11.86)^{* *}$

0.166

$(6.99)^{* *}$

0.127

$(5.50)^{* *}$

$-0.018$

$(-2.15)^{* *}$

0.126

$(4.37)^{* *}$

0.068

(0.23)

0.025

$(5.41)^{* *}$

$-0.429$

$(-2.19)^{*}$

0.145

(0.86)

$-0.040$

(-0.18)

0.096

$(4.27)^{* *}$

$-0.103$

$(-0.59)$

No

Yes
Dep. var. INT10Y

Sample 1975-2002

(6)

(7)

OLS

IV

OLS

(8)

IV

\begin{tabular}{c|cccc}
0.406 & 0.440 & 0.415 & 0.454 & 0.379 \\
$(4.35)^{* *}$ & $(11.16)^{* *}$ & $(4.07)^{* *}$ & $(10.22)^{* *}$ & $(3.94)^{* *}$ \\
0.362 & 0.173 & 0.283 & 0.195 & 0.365
\end{tabular}

$(4.90) * *$

0.131

$(3.13)^{* *}$

$-0.031$

$(-1.99)^{* *}$

$-0.042$

$(-0.33)$

$-1.538$

$(-1.75)$

0.029

$(3.24)^{* *}$

0.410

(0.76)

0.493

(1.19)

0.346

(0.89)

0.114

$(3.29)^{* *}$

0.046

(0.07)

$(6.58)^{* *}$

$(2.89)^{* *}$

$(6.58)^{* *}$

$(4.84)^{* *}$

0.103

$(4.36)^{* *}$

0.122

0.107

0.131

$-0.014$

$(3.57)^{* *}$

$(3.69)^{* *}$

$(3.15)^{* *}$

$(-1.17)$

0.094

$(2.87)^{* *}$

$-0.290$

(-0.68)

0.012

(1.68)*

0.547

$(7.80)^{* *}$

$-0.157$

$(-1.41)$

0.405

$(6.70)^{* *}$

0.116

$(3.96)^{* *}$

0.118

(1.41)

Yes

Yes
$(-2.34)^{* *}$

$-0.071$

$(-0.55)$

$-0.997$

$(-0.86)$

0.028

$(2.60)^{* *}$

0.982

$(2.12)^{* *}$

$-0.390$

$(-2.47)^{* *}$

0.566

$(2.60)^{* *}$

0.206

$(2.31)^{* *}$

0.543

(1.01)

Yes

No
$-0.016$

$-0.030$

$(-1.35) \quad(-1.80)^{*}$

0.095

$-0.046$

$(2.62)^{* *}$

$(-0.37)$

$-0.188$

$-1.381$

$(-0.49)$

(-1.48)

0.017

0.025

$(2.42) * *$

$(2.55)^{* *}$

0.309

0.188

(1.13)

(0.33)

0.286

0.513

(1.05)

(0.98)

0.079

0.136

(0.32)

(0.36)

0.112

0.115

$(3.62)^{* *}$

$(2.09)^{* *}$

0.074

$-0.437$

(0.34)

$(-0.55)$

No

No

Yes

Yes

413

413

413

373

367
367

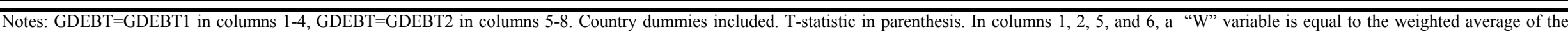

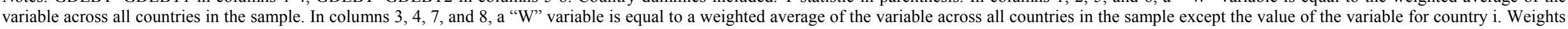
are based on real GDP. Instruments in columns 2, 4, 6, and 8 are first lag of rhs variables. See also notes to Tables 1 and 2 and section 3.4 . 


\begin{tabular}{|c|c|c|c|c|c|c|c|c|}
\hline & \multicolumn{4}{|c|}{$\begin{array}{l}\text { Dep. var. INT10Y } \\
\text { Sample 1960-2002 }\end{array}$} & \multicolumn{4}{|c|}{$\begin{array}{l}\text { Dep. var. INT10Y } \\
\text { Sample 1975-2002 }\end{array}$} \\
\hline & (1) & (2) & (3) & (4) & (5) & (6) & (7) & (8) \\
\hline & DGLS & IV & DGLS & IV & OLS & IV & OLS & IV \\
\hline \multirow[t]{2}{*}{ INT3M } & 0.368 & 0.371 & 0.406 & 0.376 & 0.436 & 0.400 & 0.438 & 0.386 \\
\hline & $(13.00)^{* *}$ & $(3.90)^{* *}$ & $(15.01)^{* *}$ & $(3.95)^{* *}$ & $(10.89)^{* *}$ & $(4.41)^{* *}$ & $(11.63)^{* *}$ & $(4.14)^{* *}$ \\
\hline \multirow[t]{2}{*}{ INFL } & 0.162 & 0.297 & 0.135 & 0.275 & 0.169 & 0.332 & 0.163 & 0.365 \\
\hline & $(7.23)^{* *}$ & $(3.64)^{* *}$ & $(5.83)^{* *}$ & $(3.30)^{* *}$ & $(5.87)^{* *}$ & $(3.70)^{* *}$ & $(5.62)^{* *}$ & $(3.92)^{* *}$ \\
\hline \multirow[t]{2}{*}{ PRDEF } & 0.150 & 0.126 & 0.319 & 0.318 & 0.129 & 0.150 & 0.253 & 0.285 \\
\hline & $(6.35)^{* *}$ & $(3.92)^{* *}$ & $(5.87)^{* *}$ & $(4.08)^{* *}$ & $(5.36)^{* *}$ & $(4.86)^{* *}$ & $(4.02)^{* *}$ & $(3.66)^{* *}$ \\
\hline \multirow[t]{2}{*}{ GDEBT } & -0.024 & -0.035 & -0.039 & -0.052 & -0.025 & -0.059 & -0.039 & -0.063 \\
\hline & $(-1.95)^{*}$ & $(-1.66)^{*}$ & $(-2.69)^{* *}$ & $(-2.41)^{* *}$ & $(-1.61)$ & $(-1.95)^{*}$ & $(-2.12)^{*}$ & $(-1.85)^{*}$ \\
\hline \multirow[t]{2}{*}{ GROWTH } & 0.147 & -0.030 & 0.125 & -0.058 & 0.064 & 0.009 & 0.054 & 0.006 \\
\hline & $(4.44)^{* *}$ & $(-0.28)$ & $(3.51)^{* *}$ & $(-0.54)$ & $(2.05)^{* *}$ & $(0.07)$ & $(1.83)^{*}$ & $(0.05)$ \\
\hline \multirow[t]{2}{*}{ PRDEF $^{2}$} & 0.573 & -1.232 & 0.248 & -1.519 & -0.344 & -1.115 & -0.433 & -1.371 \\
\hline & $(1.70)^{*}$ & $(-1.30)$ & $(0.81)$ & $(-1.65)^{*}$ & $(-0.91)$ & $(-1.21)$ & $(-1.10)$ & $(-1.46)$ \\
\hline \multirow[t]{2}{*}{ GDEBT $^{2}$} & 0.022 & 0.024 & 0.020 & 0.026 & 0.015 & 0.036 & 0.020 & 0.046 \\
\hline & $(2.31)^{* *}$ & $(1.87)^{*}$ & $(2.26)^{* *}$ & $(1.94)^{*}$ & $(1.59)$ & $(1.95)^{*}$ & $(1.84)^{*}$ & $(2.36)^{* *}$ \\
\hline \multirow[t]{2}{*}{ LIQUID LIABILITIES } & -0.012 & -0.022 & -0.033 & -0.037 & -0.022 & -0.028 & -0.030 & -0.018 \\
\hline & $(-3.11)^{* *}$ & $(-3.51)^{* *}$ & $(-3.30)^{* *}$ & $(-3.05)^{* *}$ & $(-5.44)^{* *}$ & $(-4.79)^{* *}$ & $(-3.27)^{* *}$ & $(-1.50)$ \\
\hline \multirow[t]{2}{*}{ LIQUID LIABILITIES *PRDEFY } & & & -0.230 & -0.255 & & & -0.170 & -0.159 \\
\hline & & & $(3.08)^{* *}$ & $(3.06)^{* *}$ & & & $(2.61)^{* *}$ & $(-1.90)^{*}$ \\
\hline \multirow[t]{2}{*}{ LIQUID LIABILITIES *GDEBTY } & & & 0.021 & 0.017 & & & 0.010 & -0.008 \\
\hline & & & $(1.98)^{* *}$ & $(1.50)$ & & & $(1.16)$ & $(0.74)$ \\
\hline N. of obs. & 317 & 317 & 317 & 317 & 280 & 275 & 280 & 275 \\
\hline
\end{tabular}

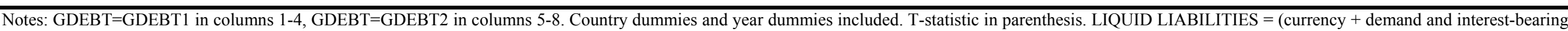
liabilities of banks and nonbank financial)/GDP. Instruments in columns 2, 4, 6, and 8 are first lag of rhs variables. See also notes to Tables 1 and 2. 


\begin{tabular}{|c|c|c|c|c|c|c|c|c|}
\hline & \multicolumn{4}{|c|}{$\begin{array}{l}\text { Dep. var. RINT10Y } \\
\text { Sample 1960-2002 }\end{array}$} & \multicolumn{4}{|c|}{$\begin{array}{l}\text { Dep. var. RINT10Y } \\
\text { Sample 1975-2002 }\end{array}$} \\
\hline & (1) & (2) & (3) & (4) & (5) & (6) & (7) & (8) \\
\hline & DGLS & IV & DGLS & IV & OLS & IV & OLS & IV \\
\hline \multirow[t]{2}{*}{ RINT3M } & 0.404 & 0.554 & 0.387 & 0.488 & 0.450 & 0.489 & 0.427 & 0.463 \\
\hline & $(15.99)^{* *}$ & $(10.69)^{* *}$ & $(15.53)^{* *}$ & $(9.38)^{* *}$ & $(11.96)^{* *}$ & $(10.20)^{* *}$ & $(12.32)^{* *}$ & $(9.52)^{* *}$ \\
\hline \multirow{2}{*}{ PRDEF } & 0.104 & 0.089 & 0.110 & 0.091 & 0.073 & 0.084 & 0.075 & 0.087 \\
\hline & $(5.23)^{* *}$ & $(3.15)^{* *}$ & $(5.72)^{* *}$ & $(3.34)^{* *}$ & $(3.60)^{* *}$ & $(3.24)^{* *}$ & $(3.72)^{* *}$ & $(3.42)^{* *}$ \\
\hline \multirow{2}{*}{ GDEBT } & -0.039 & -0.038 & -0.028 & -0.045 & -0.016 & -0.018 & -0.019 & -0.027 \\
\hline & $(-5.32)^{* *}$ & $(-3.66)^{* *}$ & $(-4.00)^{* *}$ & $(-4.53) * *$ & $(-1.44)$ & $(-1.49)$ & $(-1.87)^{*}$ & $(-2.44)^{*}$ \\
\hline \multirow[t]{2}{*}{ GROWTH } & 0.085 & 0.074 & 0.080 & 0.001 & 0.057 & 0.040 & 0.057 & -0.003 \\
\hline & $(3.54)^{* *}$ & $(0.86)$ & $(3.17)^{* *}$ & $(0.01)$ & $(2.23)^{*}$ & $(0.47)$ & $(1.93)^{*}$ & $(-0.04)$ \\
\hline \multirow[t]{2}{*}{ PRDEF $^{2}$} & 1.109 & -0.629 & 0.539 & -1.194 & -0.164 & -0.318 & -0.471 & -0.996 \\
\hline & $(3.73)^{* *}$ & $(-0.84)$ & $(1.92)^{*}$ & $(-1.35)$ & $(-0.39)$ & $(-0.43)$ & $(-1.24)$ & $(-1.05)$ \\
\hline \multirow[t]{2}{*}{ GDEBT $^{2}$} & 0.027 & 0.027 & 0.023 & 0.031 & 0.012 & 0.013 & 0.015 & 0.020 \\
\hline & $(6.66)^{* *}$ & $(4.19)^{* *}$ & $(5.83)^{* *}$ & $(4.78)^{* *}$ & $(1.85)^{*}$ & $(1.82)^{*}$ & $(2.46)^{* *}$ & $(2.62)^{* *}$ \\
\hline \multirow[t]{2}{*}{ INFL } & & & 0.405 & 0.581 & & & 0.522 & 0.579 \\
\hline & & & $(5.66)^{* *}$ & $(3.02)^{* *}$ & & & $(5.14)^{* *}$ & $(2.73)^{* *}$ \\
\hline N. of obs. & 413 & 413 & 413 & 413 & 373 & 367 & 373 & 367 \\
\hline
\end{tabular}

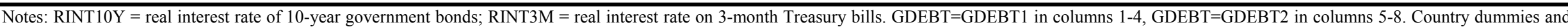
year dummies included. T-statistic in parenthesis. Instruments in columns 2, 4, 6, and 8 are first lag of rhs variables. See also notes to Tables 1 and 2. 


\begin{tabular}{|c|c|c|c|c|c|c|c|c|}
\hline & \multicolumn{4}{|c|}{$\begin{array}{l}\text { Dep. var. (INT10Y-INT3M) } \\
\text { Sample 1960-2002 }\end{array}$} & \multicolumn{4}{|c|}{$\begin{array}{l}\text { Dep. var. (INT10Y-INT3M) } \\
\text { Sample 1975-2002 }\end{array}$} \\
\hline & (1) & (2) & (3) & (4) & (5) & (6) & (7) & (8) \\
\hline & DGLS & IV & DGLS & IV & OLS & IV & OLS & IV \\
\hline \multirow[t]{2}{*}{ PRDEF } & 0.159 & 0.152 & 0.142 & 0.151 & 0.108 & 0.141 & 0.108 & 0.142 \\
\hline & $(4.29)^{* *}$ & $(3.38)^{* *}$ & $(3.78)^{* *}$ & $(3.21)^{* *}$ & $(3.33)^{* *}$ & $(3.20)^{* *}$ & $(3.28)^{* *}$ & $(3.13)^{* *}$ \\
\hline \multirow{2}{*}{ GDEBT } & -0.068 & -0.067 & -0.068 & -0.066 & -0.029 & -0.049 & -0.029 & -0.050 \\
\hline & $(-5.04)^{* *}$ & $(-4.50) * *$ & $(-5.07)^{* *}$ & $(-4.46)^{* *}$ & $(-1.91)^{*}$ & $(-2.86)^{* *}$ & $(-1.90)^{*}$ & $(-2.84)^{* *}$ \\
\hline \multirow[t]{2}{*}{ GROWTH } & 0.008 & -0.045 & 0.001 & -0.039 & 0.130 & -0.028 & 0.129 & -0.031 \\
\hline & $(0.20)$ & $(-0.31)$ & $(0.03)$ & $(-0.30)$ & $(2.60)^{* *}$ & $(-0.19)$ & $(2.48)^{* *}$ & $(-0.22)$ \\
\hline \multirow[t]{2}{*}{ PRDEF $^{2}$} & -1.027 & -2.982 & -0.536 & -2.893 & -1.164 & -2.887 & -1.156 & -2.951 \\
\hline & $(-1.90)^{*}$ & $(-2.50)^{* *}$ & $(-0.97)$ & $(-2.24)^{* *}$ & $(-2.05)^{*}$ & $(-2.32)^{*}$ & $(-2.03)^{*}$ & $(-2.16)^{*}$ \\
\hline \multirow[t]{2}{*}{ GDEBT $^{2}$} & 0.045 & 0.041 & 0.045 & 0.041 & 0.022 & 0.032 & 0.021 & 0.033 \\
\hline & $(5.63)^{* *}$ & $(4.72)^{* *}$ & $(5.79)^{* *}$ & $(4.41)^{* *}$ & $(2.34)^{* *}$ & $(3.08)^{* *}$ & $(2.30)^{* *}$ & $(2.84)^{* *}$ \\
\hline \multirow[t]{2}{*}{ INFL } & & & -0.047 & -0.015 & & & -0.005 & 0.013 \\
\hline & & & $(-1.51)$ & $(-0.28)$ & & & $(-0.16)$ & $(0.19)$ \\
\hline N. of obs. & 414 & 414 & 414 & 414 & 373 & 368 & 373 & 368 \\
\hline
\end{tabular}

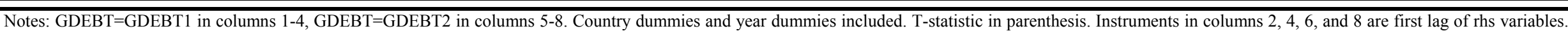
See also notes to Tables 1 and 2 . 
Sample 1975-2002

Dep. var. SW10Y

IV

(2)

0.292

(1.66)

0.325

(1.19)

0.129

$(2.33)^{* *}$

0.015

$-0.003$

$(0.51)$

$-0.080$

(0.58)

$(0.97)$

$-0.653$

(0.73)

$-0.012$

(-1.04)

189

$-0.005$

190

\section{Dep. var. (INT10Y-SW10Y)}

OLS

IV

(3)

0.018

0.074

(1.23)

(0.94)

0.005

$-0.038$

(0.20)

(0.32)

$-0.004$

0.020

$(-0.43)$

(0.93)

0.004

0.002

(0.66)

(0.23)

0.027

0.076

$(2.68)^{* *}$

(1.46)

$-0.045$

$-0.394$

$(-0.26)$

(0.97)

0.001

0.000

$(-0.78)$

(0.30)

(0.06)

189

190

N. of obs.

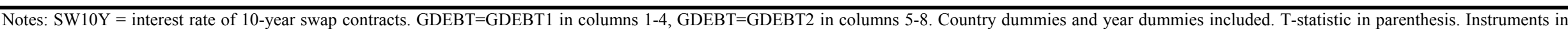
columns 2 , and 4 are first lag of rhs variables. See also notes to Tables 1 and 2. 
Table 10: Long-term interest rates and fiscal policy - Dynamic estimates

\begin{tabular}{|c|c|c|c|c|c|c|c|}
\hline San & & & & & & & \\
\hline & 0 year & 1 year & 2 years & 5 years & 10 years & Sum 0 to 5 years & Sum 0 to 10 years \\
\hline \multicolumn{8}{|l|}{ Part Ia } \\
\hline PRDEF & $0.068^{* *}$ & $0.086^{* *}$ & $0.115^{* *}$ & $0.168^{* *}$ & $0.228 * *$ & $0.661 * *$ & $1.456^{* *}$ \\
\hline GDEBT & $-0.038^{* *}$ & $-0.091 * *$ & $-0.098 * *$ & $-0.036^{* *}$ & $0.06^{* *}$ & $-0.364 * *$ & $-0.151 * *$ \\
\hline \multicolumn{8}{|l|}{ Part Ib } \\
\hline PRDEF & $0.085^{* *}$ & $0.126^{* *}$ & $0.158^{* *}$ & $0.184 * *$ & $0.202 * *$ & $0.82 * *$ & $1.52 * *$ \\
\hline GDEBT & $-0.024 * *$ & $-0.071 * *$ & $-0.073 * *$ & $-0.0073 * *$ & $0.092 * *$ & $-0.235^{* *}$ & $0.089^{* *}$ \\
\hline \multicolumn{8}{|l|}{ Part IIa } \\
\hline PRDEF & $0.08 * *$ & $0.121^{* *}$ & $0.157^{* *}$ & $0.201 * *$ & $0.243 * *$ & $0.844^{* *}$ & $1.69 * *$ \\
\hline GDEBT & $-0.006^{* *}$ & $-0.012 * *$ & $-0.003 * *$ & $0.055^{* *}$ & $0.14^{* *}$ & $0.081 * *$ & $0.57 * *$ \\
\hline \multicolumn{8}{|l|}{ Part IIb } \\
\hline PRDEF & $0.082 * *$ & $0.124^{* *}$ & $0.158^{* *}$ & $0.184^{* *}$ & $0.201 * *$ & $0.819 * *$ & $1.52 * *$ \\
\hline GDEBT & $0.006^{* *}$ & $0.007 * *$ & $0.021 * *$ & $0.083^{* *}$ & $0.17 * *$ & $0.21^{* *}$ & $0.80^{* * *}$ \\
\hline
\end{tabular}

